\title{
KARAKTERISTIK ALTERASI DAN TEKSTUR URAT KUARSA PADA PIT BARANI, CEBAKAN EMAS MARTABE, KABUPATEN TAPANULI SELATAN, PROVINSI SUMATRA UTARA
}

\section{ALTERATION AND QUARTZ-VEIN TEXTURES CHARACTERISTIC AT BARANI PIT OF MARTABE GOLD DEPOSITS, SOUTH TAPANULI REGENCY, NORTH SUMATRA PROVINCE}

\author{
Nada Salsabila Deva ${ }^{1}$, Euis Tintin Yuningsih ${ }^{1}$, Kurnia Arfiansyah Fachrudin ${ }^{1}$, \\ Nur Afrianti Saala ${ }^{2}$, dan Ade Triyunita ${ }^{2}$ \\ ${ }^{1}$ Fakultas Teknik Geologi, Universitas Padjadjaran, \\ ${ }^{2} \mathrm{PT}$. Agincourt Resources Martabe \\ nada16005@mail.unpad.ac.id
}

\begin{abstract}
ABSTRAK
Pit Barani merupakan bagian dari wilayah kontrak karya PT Agincourt Resources yang terletak di Kelurahan Aek Pining, Kecamatan Batangtoru, Kabupaten Tapanuli Selatan, Sumatra Utara. Pit Barani berupa tambang terbuka, dengan tipe cebakan epitermal berupa urat-urat yang menjadi tempat konsentrasi lebih banyak unsur logam. Penelitian bertujuan untuk mengetahui karakteristik alterasi dan variasi tekstur urat kuarsa yang banyak terdapat pada daerah Pit Barani dan mengidentifikasi tekstur urat kuarsa pembawa mineralisasi yang ekonomis. Pengambilan conto batuan dilakukan pada saat pemetaan pit dan identifikasi mineral alterasi menggunakan analisis laboratorium berupa analytical spectral devices (ASD), serta analisis geokimia untuk mengetahui kadar unsur $\mathrm{Au}, \mathrm{Ag}$, dan $\mathrm{Cu}$. Hasil penelitian menunjukkan zona alterasi yang berkembang terdiri dari zona alterasi argilik (kaolinit+illit+smektit), argilik lanjut (kuarsa+kaolinit+dikit), dan silisifikasi (kuarsa+kalsedon+kaolinit). Tekstur urat kuarsa yang berkembang pada daerah penelitian terdiri dari masif, crustiform, crustiform-colloform, brecciated, bladed, dan saccharoidal. Tekstur urat kuarsa pembawa mineralisasi dengan kadar emas tinggi berupa crustiformcolloform, banded diikuti oleh massive quartz oxide, dan lattice bladed. Urat kuarsa tersebut berasosiasi dengan mineral lempung kaolinit+dikit dengan tingkat oksidasi sedang sampai tinggi, serta berasosiasi dengan sulfida abu-abu yang mengandung kadar tertinggi mencapai Au 76,65 ppm dan Ag 34 ppm.
\end{abstract}

Kata kunci: alterasi, argilik lanjut, crustiform-colloform banded, mineralisasi, tekstur kuarsa

\section{ABSTRACT}

Barani Pit is part of the PT Agincourt Resources Contract of Work, located in Aek Pining Village, Batangtoru District, South Tapanuli Regency, North Sumatra. The Barani Pit is an open pit mine, with epithermal deposit type in the form of veins which host for more concentration of metal elements. This study aims to find out the alteration characteristics and texture variations of quartz veins that are abundant in the Barani Pit area and to identify the texture of quartz veins carrying economic mineralization. The pit mapping method is used to get samples, and alteration mineral identification using analytical spectral devices (ASD), as well as geochemical analysis to determine grade content of $\mathrm{Au}, \mathrm{Ag}$, and Cu elements. The results showed that the developing alteration zone consisted of argillic (kaolinite+illite+ smectite), advanced argillic (quartz+kaolinite+dickite), and silicification (quartz+chalcedony+ kaolinite). Quartz textures of the veins that developed in the study area consisted of massive quartz, crustiform, crustiform-colloform, brecciated, bladed, and saccharoidal. The texture of mineralization bearing veins with high grade gold content were crustiform-colloform, banded, 


\section{MAKALAH ILMIAH}

followed by massive quartz oxide, and lattice bladed. These veins are associated with kaolinite + dickite clay minerals, moderate to high oxidation states, and are associated with grey sulphides containing high grade up to Au 76.65 ppm and Ag 34 ppm.

Keywords: alteration, advanced argillic, crustiform-colloform, banded, mineralization, quartz texture

\section{PENDAHULUAN}

Daerah penelitian berada pada Pit Barani yang merupakan tambang emas terbuka pada wilayah kontrak karya PT Agincourt Resources di Kecamatan Batang Toru, Kabupaten Tapanuli Selatan, Sumatra Utara. Wilayah Martabe terletak pada fisiografi Barisan Barat, yang meliputi zona subduksi pada bagian barat dan Bukit Barisan pada bagian timur di Sumatra Utara. Wilayah ini terletak dalam Sistem Sesar Sumatra yang secara lokal dikenal sebagai Sesar Sibolga dan Sesar AngkolaGadis, serta zona pengangkatan secara struktural pada batuan meta-sedimen, batuan sedimen, vulkanoklastik, dan batuan vulkanik. Aktivitas tektonik diperkiran sebagai penyebab terbentuknya endapan hidrotermal, magmatisme multi fase, pembentukan breksi freatik dan freatomagmatik serta cebakan emas Martabe.

Pit Barani terletak pada bagian selatan wilayah kontrak karya, endapan ini memiliki tipe mineralisasi berupa urat sebagai tempat konsentrasi lebih banyak unsur logam. Penelitian ini bertujuan untuk mengetahui tipe alterasi dan tekstur urat kuarsa pembawa mineralisasi pada daerah penelitian.

\section{GEOLOGI REGIONAL}

Wilayah Martabe terletak pada cekungan busur depan dengan zona subduksi pada bagian barat dan vulkanisme aktif di sepanjang sisi timur Bukit Barisan. Magmatisme multifase dan periode sedimentasi berlangsung pada daerah ini. Menurut Sutopo (2013) stratigrafi daerah ini dapat dibagi menjadi beberapa unit utama yaitu : meta-sedimen karbonan kelompok Tapanuli Paleozoikum, Granit Uluala Nagodang Mesozoikum, Sedimen
Barus-Vulkanik Angkola Tersier, Kubah Dasit-Andesit dan Kompleks Diatreme Tersier Akhir (Gambar 1).

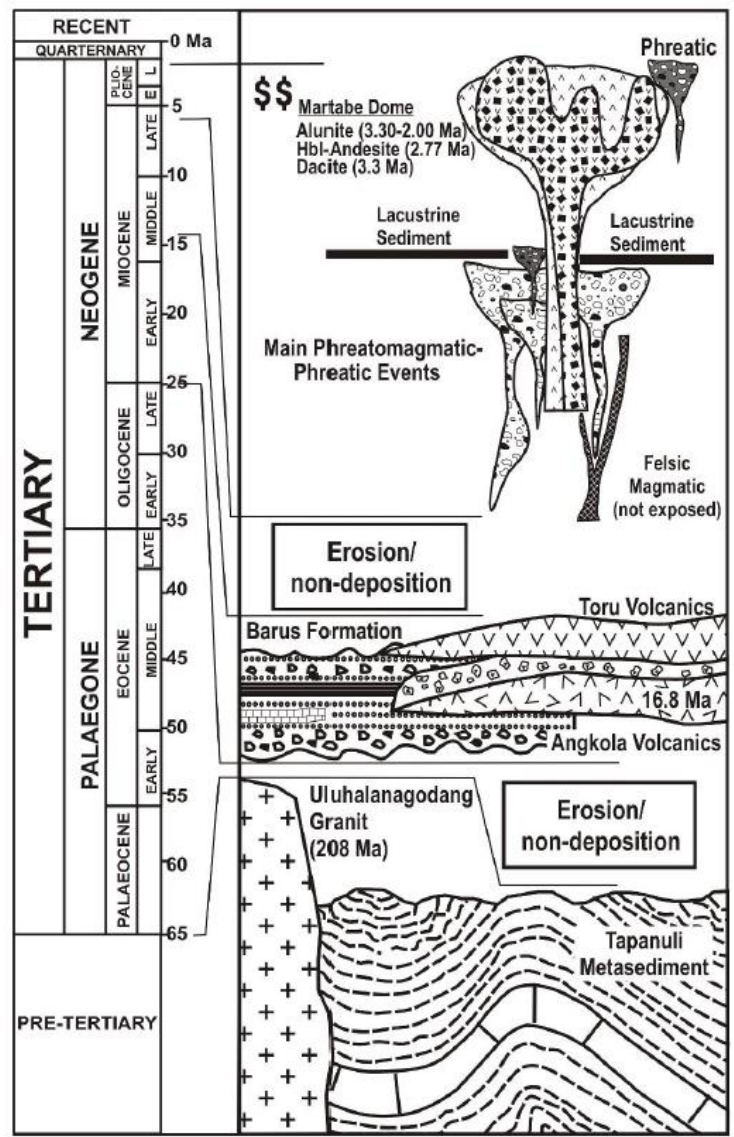

Gambar 1. Stratigrafi daerah Martabe (Sutopo, 2013)

Patahan utama pada wilayah Martabe ditafsirkan dari kelurusan dan dari pemetaan dengan arah baratlaut, utarabaratlaut hingga utara-timurlaut dan timurtimurlaut (Davies, 2002).

\section{METODE PENELITIAN}

Metode yang digunakan dalam penelitian meliputi pemetaan pit, pengambilan conto batuan permukaan dan bawah permukaan, analisis spektral, dan analisis geokimia. Pemetaan pit dilakukan dengan 
memetakan singkapan batuan, alterasi dan mineralisasi, serta pengamatan tekstur urat kuarsa. Saat pemetaan lapangan, dilakukan pengambilan conto batuan untuk kemudian dilakukan analisis spektra dan analisis geokimia. Pengambilan conto batuan dan urat kuarsa pada bawah permukaan diambil dari tujuh lubang bor batuan inti.

Analisis spectral yang dilakukan berupa Analytical Spectral Device (ASD) mempergunakan alat portable yang dilakukan di Laboratorium Eksplorasi PT Agincourt Resources, untuk mengidentifikasi mineral lempung dan mineral yang mengandung gugus $\left(\mathrm{OH}^{-}\right)$, dengan pembacaan harga panjang gelombang setiap mineral yang dikenai sinar infrared pada sensor. Analisis geokimia yang digunakan berupa uji fire assay, untuk mengetahui kandungan unsur logam ekonomis pada batuan, khususnya $\mathrm{Au}, \mathrm{Ag}$, dan $\mathrm{Cu}$. Uji fire assay dilakukan di Laboratorium Eksplorasi PT Agincourt Resources terhadap 55 conto batuan dan urat kuarsa.

\section{HASIL DAN PEMBAHASAN}

\section{Geologi Daerah Penelitian}

Daerah penelitian dibedakan menjadi lima satuan batuan dengan urutan dari tua ke muda, yaitu: satuan batupasir, satuan konglomerat, satuan breksi vulkanik, dan satuan breksi freatomagmatik (Gambar 2).

\section{Satuan Batupasir}

Litologi terdiri atas batupasir, dan setempat terdapat perselingan batupasir dengan batulanau. Batupasir halus berwarna abuabu muda sampai abu-abu kuning kemerahan, ukuran butir pasir halus sampai pasir sedang, membundar, terpilah baik, kemas tertutup, pola alterasi selective pervasive sampai pervasive, intensitas alterasi sedang. Alterasi berupa mineral lempung kaolinit dan dikit, mineral oksida hematit dan gutit, serta terdapat pirit pada beberapa tempat (Gambar 3a).

\section{Satuan Konglomerat}

Litologi terdiri atas perselingan konglomerat dengan batupasir. Konglomerat berwarna abu-abu tua kecoklatan, fragmen berupa kuarsa berbutir kasar, batupasir dan batulanau, dengan matriks batupasir. Bentuk fragmen membundar tanggung sampai menyudut tanggung, ukuran fragmen berangkal sampai butiran, terpilah buruk, dan kemas terbuka. Pola alterasi selective pervasive, dengan intensitas alterasi sedang sampai tinggi, silisifikasi, dan pada beberapa bagian teroksidasi sedang. Mineral oksida berupa hematit dan gutit (Gambar 3b).

\section{Satuan Breksi Vulkanik}

Breksi vulkanik berwarna putih kemerahan sampai putih merah kecoklatan. Monomik, andesitik klastik dengan matriks tuf. Bentuk fragmen menyudut sampai membundar tanggung, ukuran fragmen berangkal sampai kerikil, terpilah buruk, dan kemas terbuka. Batuan sudah teroksidasi kuat, pola alterasi selective pervasive sampai pervasive, intensitas alterasi sedang sampai kuat. Alterasi berupa mineral lempung kaolinit, dikit, dan mineral oksida hematit dan gutit (Gambar 3c).

\section{Satuan Breksi Freatomagmatik}

Breksi freatomagmatik berwarna abu-abu sampai merah kecoklatan. Fragmen berupa kuarsa, batuan andesitik, klastik vulkanik, dengan matriks pasiran. Bentuk fragmen menyudut sampai membundar tanggung, ukuran fragmen bongkah sampai kerakal, terpilah buruk, dan kemas terbuka. Tingkat oksidasi sedang sampai kuat, pola alterasi selective pervasive sampai pervasive, dengan intensitas alterasi sedang sampai kuat. Alterasi mineral lempung berupa ilit, smektit, kaolinit, dan dikit, dan mineral oksida jarosit, hematit, dan gutit. Pada beberapa tempat terdapat accretionary ball (Gambar 3d).

\section{Zonasi Alterasi Daerah Penelitian}

Berdasarkan pemetaan lapangan dan analisis ASD dari beberapa conto batuan, 


\section{MAKALAH ILMIAH}

menunjukkan mineral lempung berupa kaolinit, ilit, smektit, dan minor alunit sebagai penciri suatu zona alterasi yang terdapat pada daerah penelitian. Zona alterasi yang berkembang pada daerah penelitian terbagi menjadi tiga, yaitu : zona alterasi silika, zona alterasi kuarsa+kaolinit+dikit+k-alunit, dan zona alterasi kaolinit+ilit+smektit (Gambar 4).

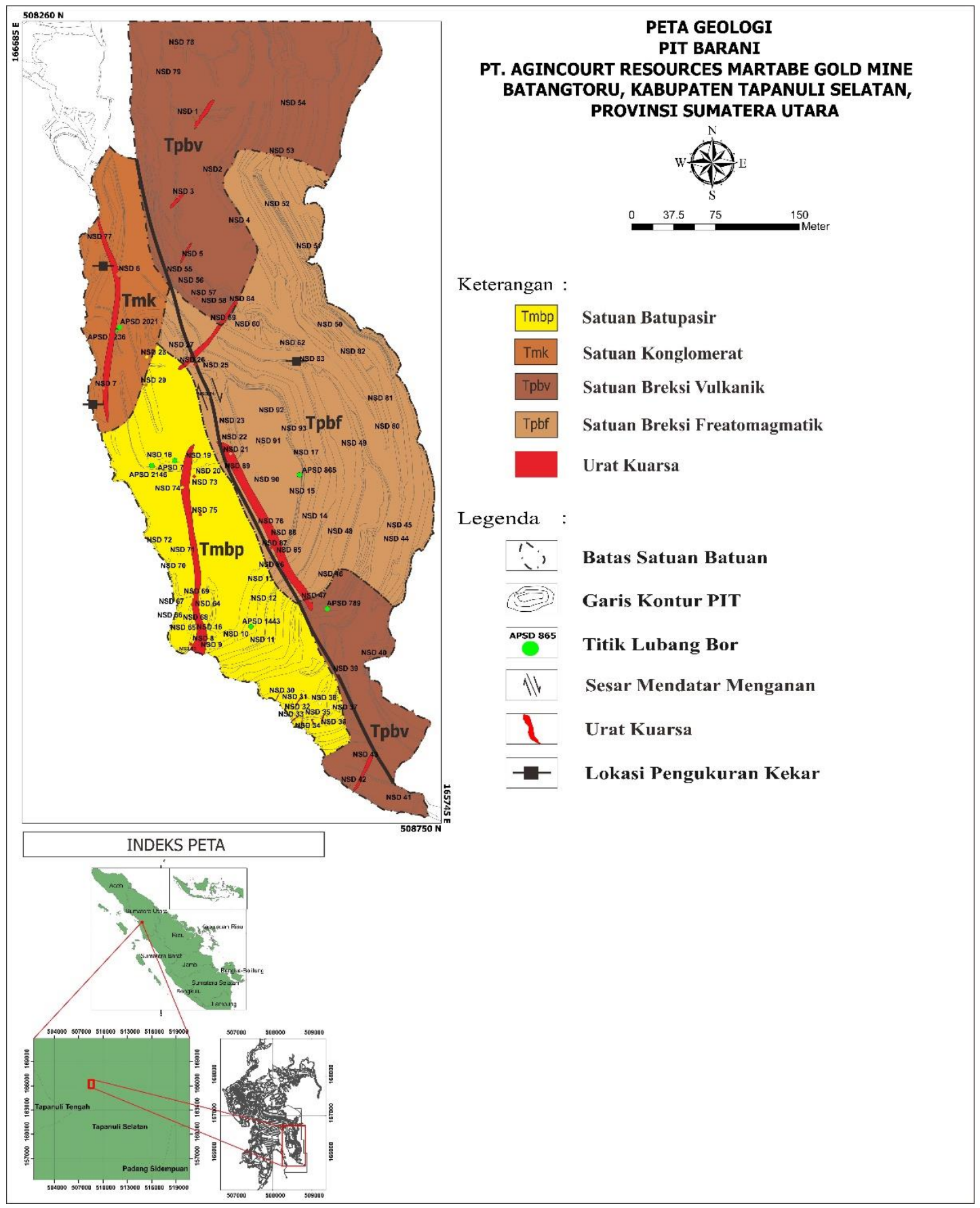

Gambar 2. Peta geologi dan lokasi pengamatan singkapan batuan pada Pit Barani 

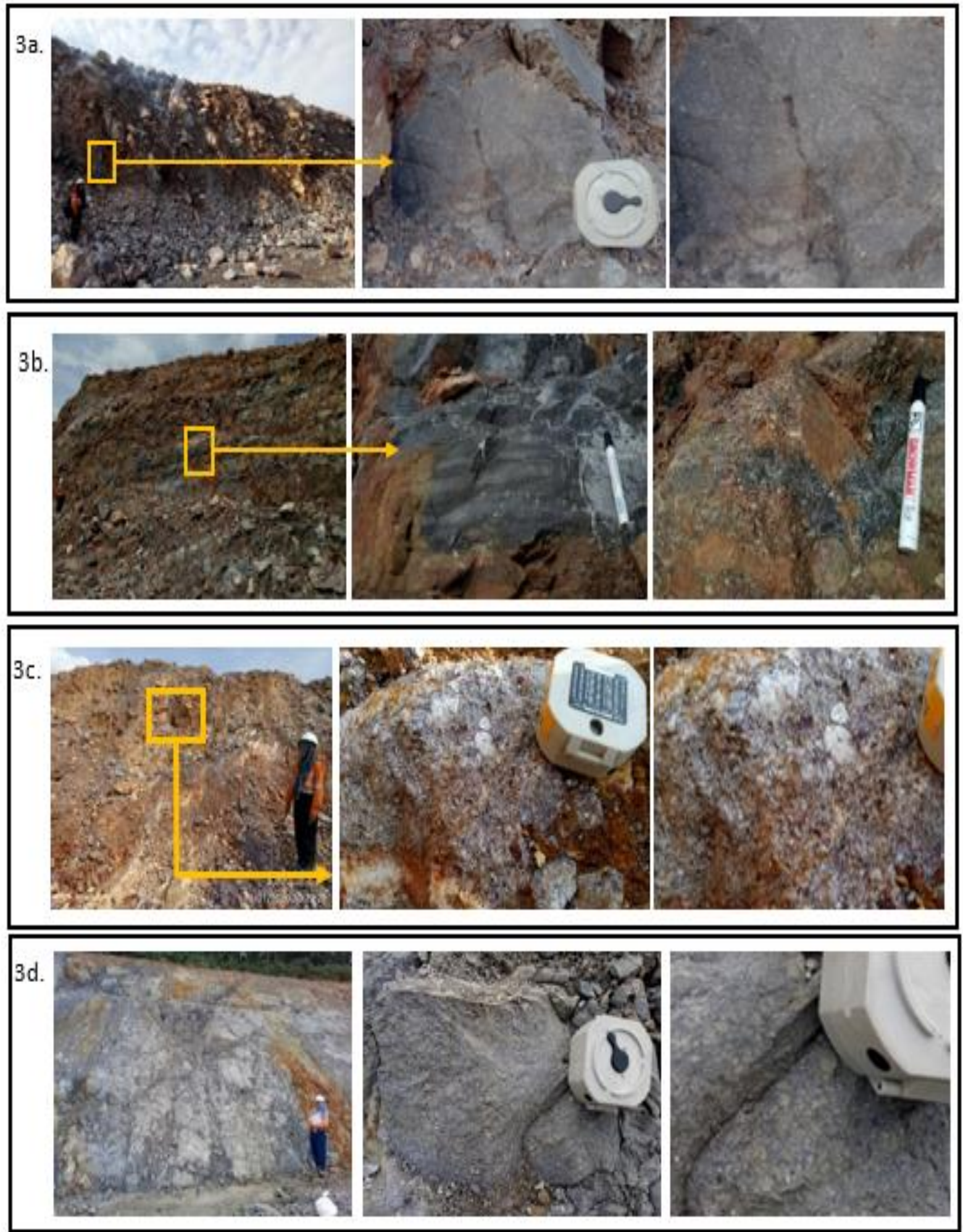

Gambar 3. Singkapan batuan yang terdapat pada Pit Barani.

3a. Batupasir pada titik pengamatan NSD 18,

3b. Konglomerat pada titik pengamatan NSD 6 ,

3c. Breksi vulkanik pada titik pengamatan NSD 01,

3d. Breksi freatomagmatik pada titik pengamatan NSD 82. 


\section{MAKALAH ILMIAH}

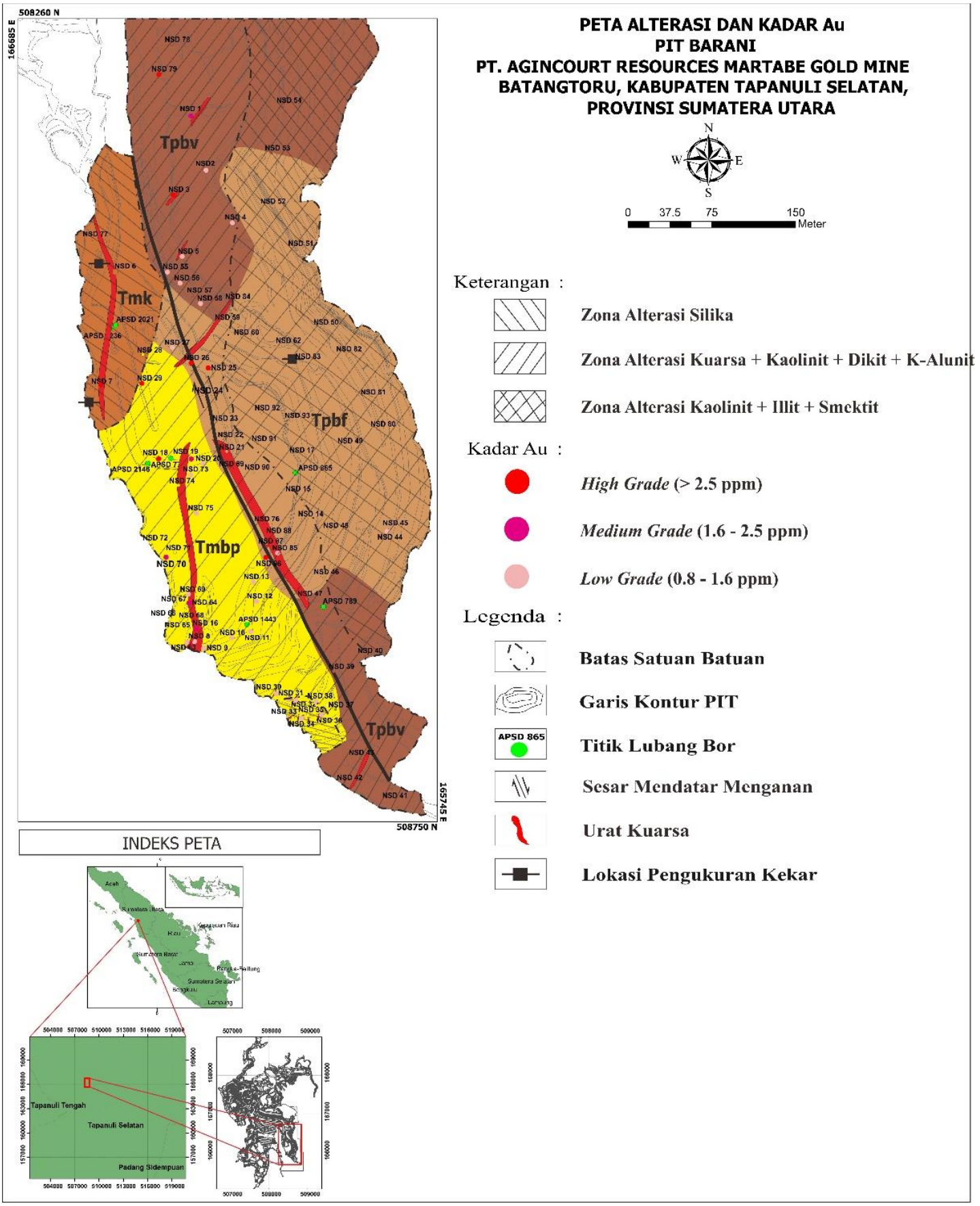

Gambar 4. Peta sebaran zona alterasi dan kadar Au pada Pit Baran.

\section{Zona Alterasi Silika}

Zona alterasi silika berwarna abu-abu sampai abu-abu tua kecoklatan, mineral alterasi berupa kuarsa dan kalsedon, terjadi penambahan atau masuknya silika oleh larutan hidrotermal (Gambar 5a). Mineralisasi pada zona alterasi ini berupa diseminasi pirit halus dan urat kuarsa. Tingkat oksidasi lemah sampai sedang, dengan mineral oksida berupa gutit dan hematit. Zona alterasi ini disebandingkan dengan zona alterasi silisifikasi yang terbentuk pada temperatur $150^{\circ}-200^{\circ} \mathrm{C}$ (Hedenquist, dkk, 1998), dengan kondisi $\mathrm{pH}<2$ (Corbet and Leach,1997).

Analisis ASD yang dilakukan pada conto batuan permukaan NSD 31, litologi batupasir silisifikasi menunjukkan mineral silika dan mineral oksida berupa gutit (Gambar 6a). 


\section{Zona Alterasi Kuarsa+Kaolinit+Dikit+ K-Alunit}

Zona alterasi kuarsa+kaolinit+dikit+k-alunit terdiri dari batuan berwarna putih keabuan sampai abu-abu kemerahan, mineral alterasi berupa mineral lempung kaolinit, dikit, dan setempat alunit (Gambar 5b). Mineralisasi pada zona alterasi ini berupa diseminasi pirit, sulfida abu-abu, dan urat kuarsa. Tingkat oksidasi sedang sampai kuat, dengan mineral oksida berupa gutit dan hematit. Zona alterasi ini disebandingkan dengan zona alterasi argilik lanjut yang terbentuk pada temperatur $150^{\circ}-200^{\circ} \mathrm{C}$ (Hedenquist, dkk, 1998), dengan kondisi $\mathrm{pH}$ asam yaitu 4 (Corbet and Leach,1997).

Analisis ASD dilakukan pada conto batuan permukaan NSD 70 litologi batupasir dan NSD 16 litologi breksi freatomagmatik. Pada litologi breksi freatomagmatik menunjukkan mineral lempung berupa kaolinit terkristalisasi baik dan k-alunit. Sedangkan pada litologi batupasir menujukkan mineral lempung berupa kaolinit terkristalisasi baik, dikit, serta mineral oksida berupa hematit dan gutit (Gambar 6b).

\section{Zona Alterasi Kaolinit+llit+Smektit}

Zona alterasi kaolinit+ilit+smektit terdiri dari batuan berwarna abu-abu muda sampai abu-abu kekuningan, mineral alterasi berupa mineral lempung kaolinit, ilit, dan smektit (Gambar 5c). Mineralisasi pada zona alterasi ini berupa diseminasi pirit dan urat kalsit setempat. Tingkat oksidasi sedang sampai kuat, dengan mineral oksida berupa jarosit dan beberapa tempat limonit. Zona alterasi ini disebandingkan dengan zona alterasi argilik yang terbentuk pada temperatur $150^{\circ}-250^{\circ} \mathrm{C}$ (Hedenquist, dkk, 1998), dengan kondisi pH 4-6 (Corbet and Leach,1997).
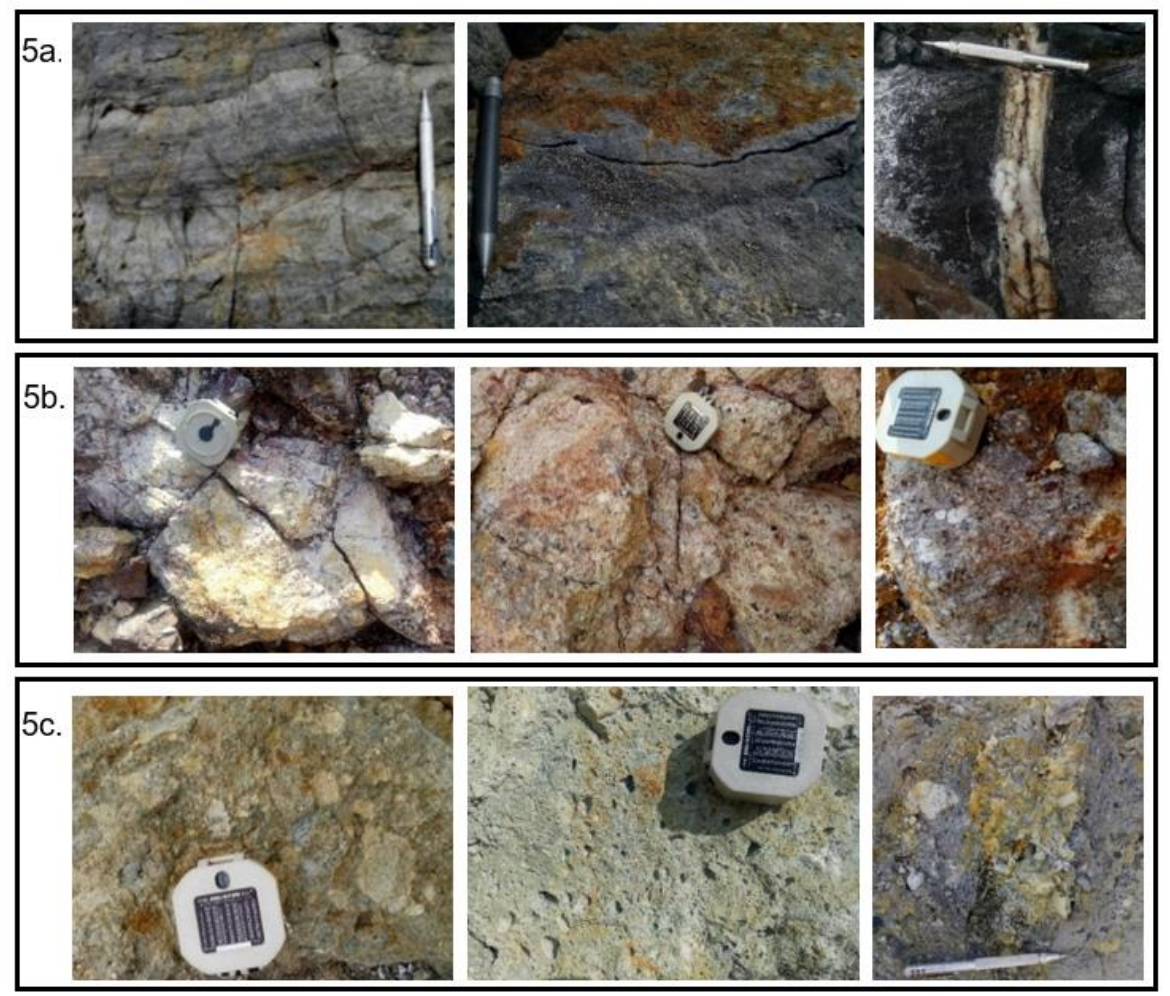

Gambar 5. Batuan teralterasi pada daerah penelitian. 5a. Alterasi silika yang terdapat pada litologi perselingan batupasir dengan konglomerat dan litologi batupasir yang telah mengalami silisifikasi, terdapat pirit dan setempat urat kuarsa pada titik pengamatan NSD 6 ,

5b. Alterasi kuarsa+kaolinit+dikit+k-alunit yang terdapat pada litologi breksi vulkanik pada NSD 2, 5c. Alterasi kaolinit+ilit+smektit yang terdapat pada litologi breksi freatomagmatik pada NSD 81 


\section{MAKALAH ILMIAH}

Analisis ASD yang dilakukan pada conto batuan permukaan NSD 48 litologi breksi freatomagmatik menunjukkan mineral lempung berupa illit dan smektit, serta mineral oksida berupa jarosit (Gambar 6c).

\section{Karakteristik Tekstur Urat Kuarsa Pada Pit Barani}

Pengambilan dan pengamatan conto urat dilakukan pada permukaan Pit Barani dan beberapa titik lubang bor yang telah ditentukan. Pada Pit Barani terdapat tujuh zona urat (Gambar 7). Arah urat pada daerah penelitian mengikuti segmen patahan dari Sistim Sesar Sumatra yang berarah tenggara-baratlaut.
Zona Urat berarah tenggara-baratlaut pada satuan breksi vulkanik dan breksi freatomagmatik

Urat memiliki arah umum $\mathrm{N} 170^{\circ} \mathrm{E}$, dengan dip $72^{\circ}$. Dimensi urat dengan panjang mencapai $15 \mathrm{~m}$ dan lebar $8 \mathrm{~m}$. Urat kuarsa terdapat pada litologi breksi vulkanik dan breksi freatomagmatik dengan intensitas alterasi kuat, pola alterasi pervasive sampai selective pervasive, intensitas oksidasi sedang sampai kuat. Alterasi berupa mineral lempung kaolinit, dikit, k-alunit, mineral oksida berupa hematit, gutit, dan setempat jarosit. Tekstur kuarsa yang berkembang adalah tekstur custiform banded quartz with oxide, dan crustiform-colloform yang terdapat pada dinding Pit Barani.
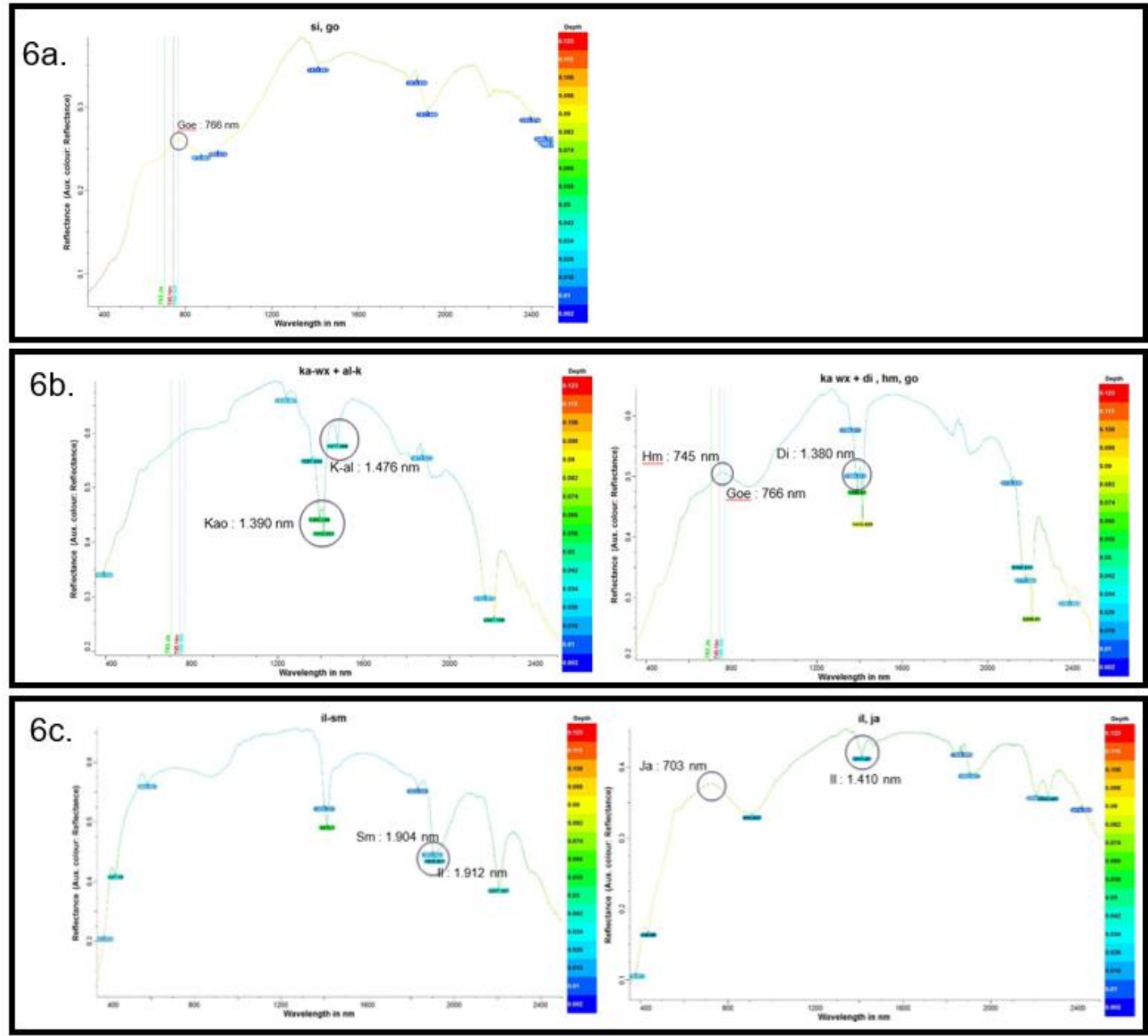

Gambar 6. Spektrum pembacaan mineral lempung. 6a. Menunjukkan mineral gutit pada titik pengamatan NSD 31, 6b. Mineral kaolinit terkristalisasi baik, dikit, k-alunit, hematit, dan gutit pada titik pengamatan NSD 70 dan NSD 16, 6c. Mineral illit, smektit, dan jarosit pada titik pengamatan NSD 48 


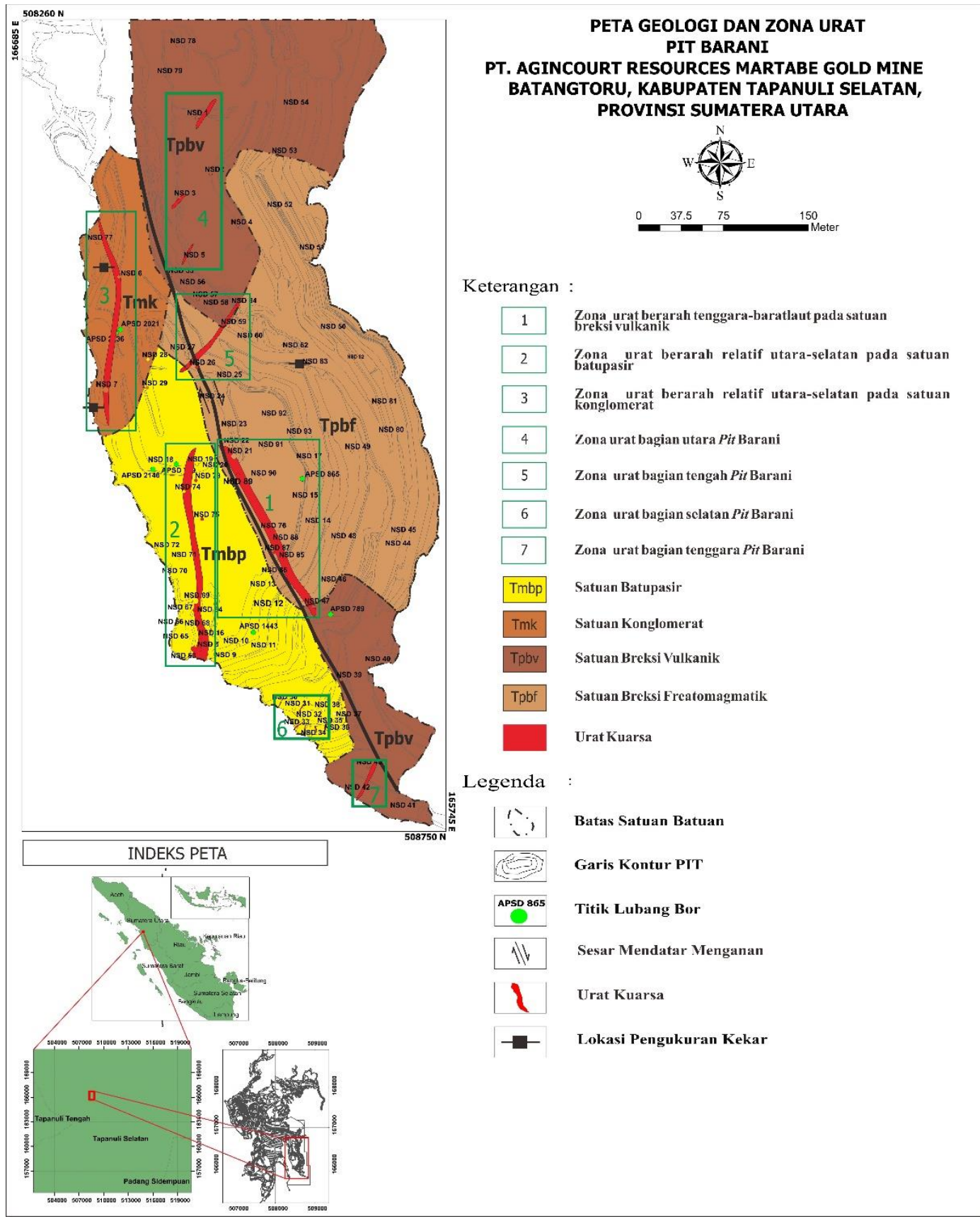

Gambar 7. Peta geologi dan zona urat pada Pit Barani

Zona urat berarah relatif utara - selatan pada satuan batupasir

Urat memiliki arah umum $\mathrm{N} 195^{\circ} \mathrm{E}$, dengan dip $75^{\circ}$. Dimensi urat dengan panjang mencapai $9 \mathrm{~m}$ dan lebar $3 \mathrm{~m}$. Urat kuarsa terdapat pada litologi batupasir dengan intensitas alterasi sedang sampai kuat, pola alterasi pervasive sampai selective pervasive, intensitas oksidasi sedang sampai kuat. Alterasi berupa mineral lempung kaolinit, dikit, k-alunit, mineral oksida berupa hematit dan gutit. Tekstur kuarsa yang berkembang adalah tekstur custiform banded dan crustiform-colloform yang terdapat pada bagian dinding Pit Barani.

\section{Zona urat berarah relatif utara - selatan pada satuan konglomerat}

Urat memiliki arah umum $\mathrm{N} 170^{\circ} \mathrm{E}$, dengan dip $42^{\circ}$. Dimensi urat dengan panjang mencapai $12 \mathrm{~m}$ dan lebar $5 \mathrm{~m}$. Urat kuarsa terdapat pada litologi perselingan batupasir dan konglomerat dengan intensitas alterasi 
lemah sampai sedang, pola alterasi pervasive, intensitas oksidasi sedang sampai kuat. Alterasi silisifikasi, mineral oksida berupa hematit dan gutit. Tekstur kuarsa yang berkembang adalah brecciated, saccharoidal, dan massive oxide quartz yang terdapat pada dinding Pit Barani.

\section{Urat bagian utara Pit Barani}

Urat pada bagian utara memiliki arah umum $\mathrm{N} 210^{\circ} \mathrm{E}$, dengan dip $68^{\circ}$. Dimensi urat dengan panjang 4,2 $\mathrm{m}$ dan lebar 2,2 m, dan veinlets dengan lebar maksimum 30 $\mathrm{cm}$. Urat kuarsa terdapat pada litologi breksi vulkanik dengan intensitas alterasi sedang sampai kuat, pola alterasi selective pervasive sampai pervasive, intensitas oksidasi sedang sampai kuat. Alterasi berupa mineral lempung kaolinit, dikit, kalunit, mineral oksida berupa hematit dan gutit, setempat terdapat mineral jarosit. Tekstur kuarsa yang berkembang adalah custiform banded quartz with oxide dan terdapat bladed quartz pada dinding Pit Barani.

\section{Urat bagian tengah Pit Barani}

Urat pada bagian tengah Pit Barani memiliki arah umum $\mathrm{N} 210^{\circ} \mathrm{E}$, dengan dip $65^{\circ}$. Dimensi panjang urat mencapai $4,2 \mathrm{~m}$ dan lebar 2,2 m, serta terdapat veinlets dengan dimensi maksimum $10 \mathrm{~cm}$. Urat kuarsa terdapat pada litologi breksi vulkanik dengan intensitas alterasi sedang sampai kuat, pola alterasi pervasive sampai intens, intensitas oksidasi sedang sampai kuat. Alterasi berupa mineral lempung kaolinit dan dikit, mineral oksida berupa hematit dan gutit. Tekstur kuarsa masif pada dinding Pit Barani.

\section{Urat bagian selatan Pit Barani}

Urat pada bagian selatan Pit Barani memiliki arah umum $\mathrm{N} 210^{\circ} \mathrm{E}$, dengan dip $65^{\circ}$. Dimensi panjang urat mencapai $4,2 \mathrm{~m}$ dan lebar 2,2 m. Urat kuarsa terdapat pada litologi batupasir dengan intensitas alterasi sedang sampai kuat, pola alterasi pervasive sampai intens, intensitas oksidasi sedang sampai kuat. Alterasi berupa mineral lempung kaolinit, dikit, mineral oksida didominasi oleh hematit dan gutit. Tekstur kuarsa yang dijumpai adalah masif dan massive oxide quartz pada dinding Pit Barani.

\section{Urat bagian tenggara Pit Barani}

Urat pada bagian tenggara Pit Barani memiliki arah umum $\mathrm{N} 210^{\circ} \mathrm{E}$, dengan dip $65^{\circ}$. Dimensi panjang mencapai $4,2 \mathrm{~m}$ dan lebar 2,2 m. Urat kuarsa terdapat pada litologi breksi vulkanik yang sudah mengalami alterasi dengan intensitas alterasi sedang sampai kuat, pola alterasi pervasive, intensitas oksidasi sedang sampai kuat, mineral oksida didominasi oleh hematit, gutit, dan setempat jarosit, sedangkan mineral lempung berupa kaolinit dan dikit. Tekstur kuarsa yang dijumpai adalah masif pada dinding Pit Barani.

Urat kuarsa pada daerah penelitian terdapat pada alterasi silisifikasi (zona alterasi silika) dan argilik lanjut (zona alterasi kuarsa+kaolinit+dikit), dimana proses penambangan dominan dilakukan pada zona alterasi kuarsa+kaolinit+dikit (argilik lanjut), oksidasi yang berkembang pada zona alterasi tersebut memiliki tingkat oksidasi sedang sampai kuat, dengan mineral oksida berupa hematit, gutit, dan setempat jarosit.

Hasil pengamatan tekstur yang dilakukan dari pengamatan permukaan pada lapangan dan beberapa titik lubang bor menunjukkan tekstur urat yang cukup beragam. Hasil pengamatan megaskopis menunjukkan tekstur mulai dari masif, crustiform banded, crustiform-colloform, brecciated, lattice bladed, dan saccharoidal.

\section{- Masif}

Kenampakan tekstur masif mencirikan adanya pengendapan larutan silika hidrotermal yang homogen tanpa adanya tekstur lain seperti banding dan rekahan (Dong, dkk, 1995). Urat kuarsa masif berwarna putih, putih kecoklatan, komposisi mineral terdiri dari kuarsa, mengalami oksidasi yang cukup tinggi, mengandung Au 95 ppm, Ag 2 ppm dan $\mathrm{Cu}$ 4 ppm (Gambar 8a). 


\section{- Crustiform}

Tekstur ini memiliki kenampakan perlapisan yang simetris, sempit, dan berulang hingga beberapa sentimeter (Dong, dkk, 1995). Hal ini mengindikasikan adanya perbedaan tekstur, proporsi mineral atau warna. Tekstur Crustiform berwarna putih kekuningan sampai krem dengan komposisi mineral kuarsa dan kalsedon yang mengandung kadar mencapai Au 8.76 ppm, Ag 1 ppm, dan $\mathrm{Cu}$ 16 ppm (Gambar 8e).

\section{- Crustiform - Colloform}

Tekstur crustiform memiliki kenampakan perlapisan yang simetris, sempit, dan berulang. Sebagai indikasi adanya perubahan pada kondisi fluida hidrotermal saat pembentukan urat, sehingga akan membentuk tekstur mineral seperti ukuran butir, warna, dan proporsi mineral yang berbeda. Tekstur colloform mengindikasikan larutan silika berupa gel dari mineral kalsedon yang memiliki butir sangat halus (Dong, dkk, 1995). Tekstur crustiform-colloform berwarna putih keabuabuan sampai krem kecoklatan, komposisi mineral kuarsa, kuarsa mikrokristalin, kalsedon, dan lineasi sulfida abu-abu, setempat sudah mengalami oksidasi dengan kandungan kadar tinggi mencapai Au 76,65 ppm, dan Ag 34 ppm (Gambar 8 $c, d)$.

\section{- Brecciated}

Rekahan pada batuan samping diakibatkan oleh pertemuan fluida bersuhu tinggi dengan fluida yang bersuhu lebih rendah yang menyebabkan tekanan menjadi tinggi dan menghancurkan batuan samping yang dilewatinya (Dowling dan Morrison, 1990). Tekstur terbreksikan berwarna abu-abu kecoklatan, komponen berupa batupasir, batulempung, dengan matriks kuarsa. Kadar yang didapatkan pada tekstur terbreksikan Au 0,92 ppm, Ag 2 ppm, dan Cu 4 ppm Gambar 8f).

\section{- Bladed}

Tekstur lattice bladed tergolong tekstur pergantian, menurut Morrison, dkk, (1990) tekstur ini erat kaitannya dengan kondisi boiling yang terjadi pada suatu sistim geotermal. Proses penggantian berkaitan dengan terjadinya pencampuran fluida meteorik bersuhu lebih rendah dengan $\mathrm{CO}_{2}$ yang dibebaskan dari larutan hidrotermal ketika mengalami pendidihan. Tekstur bladed berwarna putih sampai coklat tua, berupa kuarsa akibat kondisi boiling dengan kadar Au 0,87 ppm, Ag 3 ppm, dan Cu 6 ppm (Gambar 8b).

Tekstur urat pada daerah penelitian terbagi menjadi dua yaitu, tekstur pertumbuhan primer dan tekstur penggantian. Tekstur pertumbuhan primer dicirikan dengan tekstur masif, crustiform, dan crustiformcolloform, sedangkan tekstur penggantian dicirikan dengan tekstur lattice bladed, dan saccharoidal.

Tekstur masif mengindikasikan proses pembentukan yang terjadi dalam satu kali periode. Secara umum, setiap proses dapat menyebabkan perubahan kondisi dan terbentuk crustiform secara sederhana. Proses tersebut termasuk pendinginan, pencampuran dua fluida, dan reaksi antara fluida dengan batuan samping. Untuk menghasilkan banding crustiform yang kompleks diperlukan banyak perubahan berulang dalam komposisi mineralnya atau penurunan tekanan, dimana penurunan tekanan ini akan memungkinkan cairan mendidih, mengakibatkan hilangnya gas, pendinginan, kelarutan $\mathrm{pH}$, presipitasi mineral lain dan gangue. Tekstur colloform disebabkan oleh adanya kristalisasi dari gel silika, dimana mengalirnya atau berpindahnya zat pengotor yang sangat lambat dibandingkan dengan laju pertumbuhan kristal, kemudian melekat pada batuan samping atau urat kuarsa. Tekstur crustiform-colloform terjadi akibat banyaknya perubahan berulang dalam komposisi mineralnya, penurunan tekanan, yang akan memungkinkan cairan mendidih, mengakibatkan terjadinya presipitasi mineral lain dan gangue. Tekstur saccharoidal merupakan hasil dari penggantian kalsit yang didistribusikan secara acak yang akhirnya saling mengikat dan membentuk tekstur saccharoidal. 


\section{MAKALAH ILMIAH}

Variasi tekstur urat pada daerah penelitian merepresentasikan

proses-proses

hidrotermal tertentu selama pembentukan endapan bijih (Gambar 9). Tahap awal terbentuknya endapan hidrotermal dicirikan dengan pembentukan urat-urat kuarsa bertekstur masif. Tahap pertengahan dicirikan dengan pembentukan urat yang diawali dengan tekstur crustiform, kemudian crustiform-colloform, dan diakhiri dengan tekstur terbreksikan. Mineralisasi terutama Au-Ag terjadi secara efektif pada tahap ini. Endapan hidrotermal tahap akhir dicirikan dengan pembentukan tekstur bladed, dan saccharoidal. Tahap supergen dicirikan dengan proses penggantian akibat oksidasi mineral yang terbentuk, tahap ini diinterpretasikan sebagai tahap terakhir dari proses mineralisasi di daerah penelitian.

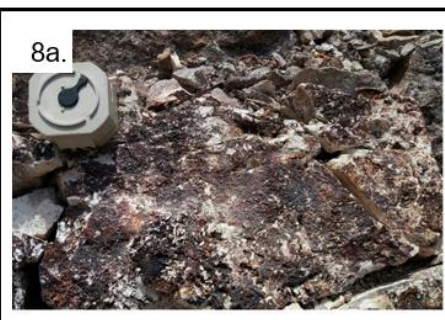

$0.95 \mathrm{ppm} \mathrm{Au}, 2 \mathrm{ppm} \mathrm{Ag}, 4$ ppm Cu
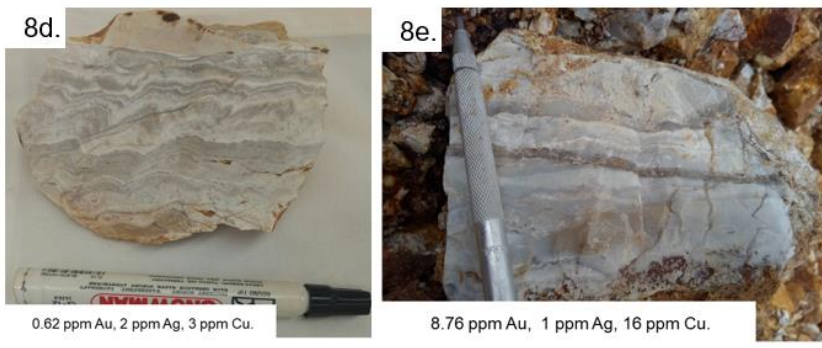
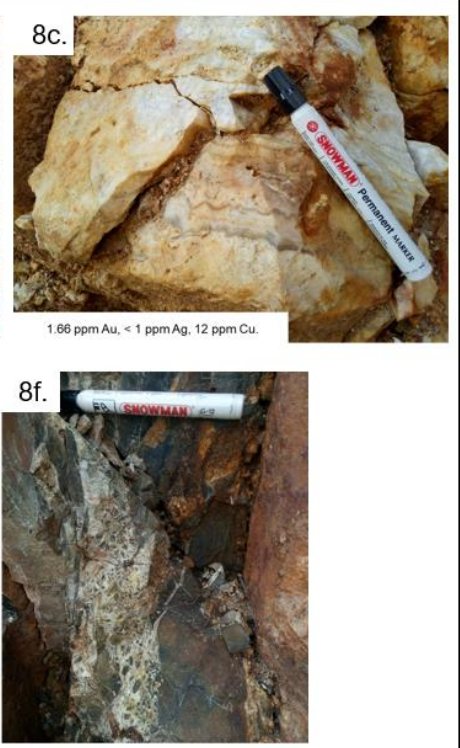

$0.92 \mathrm{ppm} \mathrm{Au}, 2 \mathrm{ppm} \mathrm{Ag}, 4 \mathrm{ppm}$ Cu.

Gambar 8. Tekstur urat kuarsa pada Pit Barani, 8a. Kuarsa masif yang terdapat pada titik pengamatan NSD 7, 8b. Bladed texture pada NSD 21,

8c-d. Crustiform-colloform texture pada NSD 9 dan NSD 69,

8e. Crustiform texture pada NSD 63, dan 8f. Brecciated texture pada NSD 7

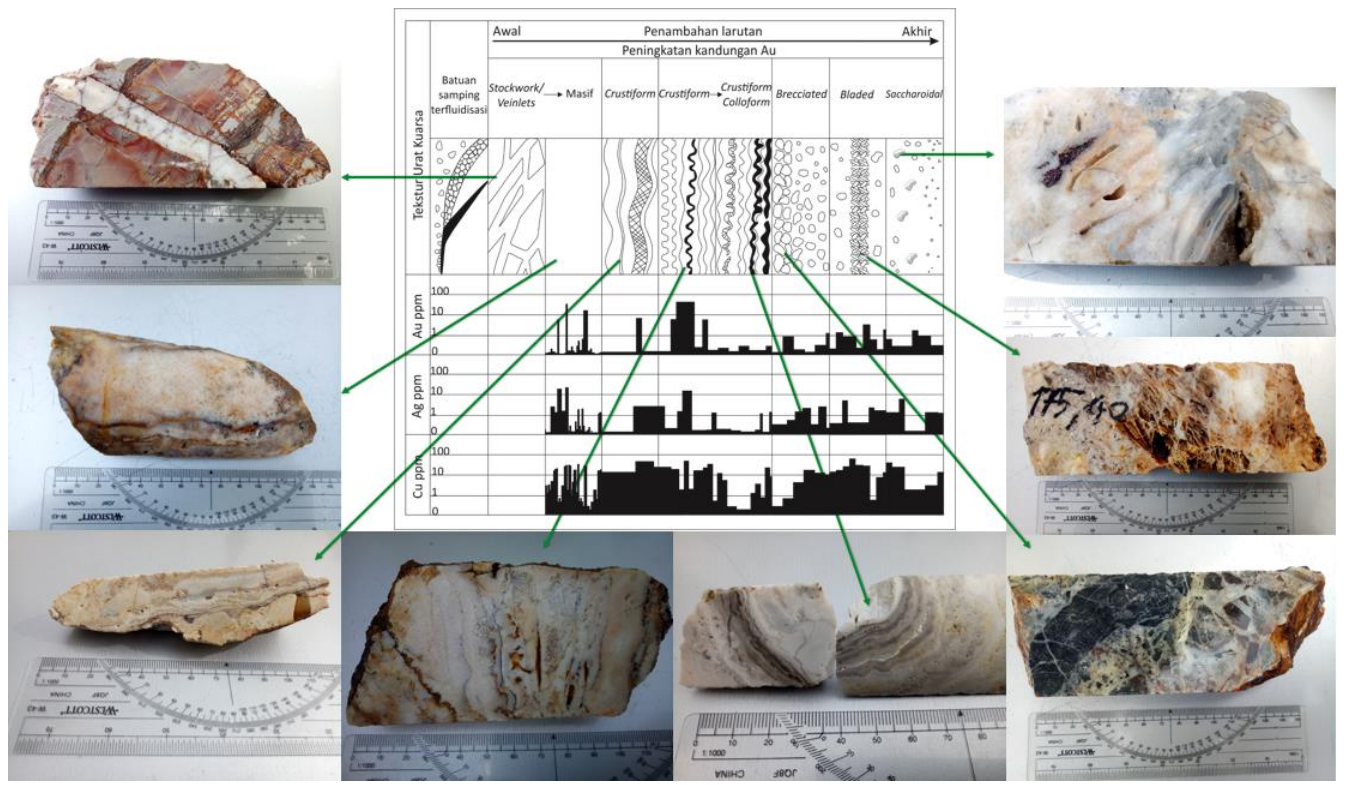

Gambar 9. Urutan tahap terbentuknya endapan hidrotermal pada daerah penelitian 


\section{KESIMPULAN}

Zona alterasi yang berkembang pada daerah penelitian dikelompokkan menjadi 3 zona alterasi, yaitu zona alterasi silika yang disebandingkan dengan zona alterasi silisifikasi, zona alterasi kuarsa + kaolinit + dikit + k-alunit yang disebandingkan dengan zona alterasi argilik lanjut, dan zona alterasi kaolinit + illit + smektit yang disebandingkan dengan zona alterasi argilik. Mineralisasi yang hadir di daerah penelitian yaitu pirit, mineral oksida (jarosit, gutit, dan hematit), dan berdasarkan analisis geokimia terdapat emas, perak, tembaga, yang berasosiasi dengan urat kuarsa.

Tekstur dengan kadar Au-Ag tertinggi sebagai salah satu pengontrol pembawa mineralisasi terdapat pada tekstur crustiform-colloform. Tekstur crustiformcolloform berada pada zona alterasi kuarsa+kaolinit+dikit+k-alunit, tingkat oksidasi sedang sampai tinggi, serta berasosiasi dengan sulfida abu-abu. Kadar yang dihasilkan mencapai $\mathrm{Au}$ 76,65 ppm dan Ag 34 ppm.

\section{UCAPAN TERIMAKASIH}

Penulis mengucapkan terimakasih kepada seluruh pihak PT Agincourt Resources Martabe Gold Mine, tim Departemen Mine Geology, dan tim Departemen Eksplorasi untuk akses data, serta Fakultas Teknik Geologi Universitas Padjadjaran untuk proses administrasi pelaksanaan penelitian.

\section{DAFTAR PUSTAKA}

Alderton Conrad. 2017. Description and Comparison of the Martabe Deposits. Martabe Deposits Final, Internal Report Martabe, p. $20-24$.
Anonim. 1996. Sandi Stratigrafi Indonesia, Komisi Sandi Stratigrafi Indonesia. Ikatan Ahli Geologi Indonesia, $14 \mathrm{~h}$.

Anonim. 2009. AusSpec Workshop: Spectral Analysis and its Application to Exploration and Mining. AusSpec International, internal presentation.

Corbett, J.G., and Leach, T.M., 1997, Southwest Pacific Rim gold-copper systems: Structure, alteration, mineralization: Society of Economic Geologist Special Publication, v.6, p. $98-102$.

Davies, B., 2002. Report on the structural review of the Martabe project, Newmont Horas Nauli, internal memorandum, p 5.

Dong, G., Morrison., G and Jaireth., S., 1995. Quartz Texture in Epithermal Veins, Queensland - Classification, Origin, and Implication: Economic Geology, vol 90, p. 1841 - 1856.

Dowling, K. and Morrison, G. W., 1990. Application of quartz textures to the classification of gold deposits using North Queensland examples: Economic Geology, pp 342 - 355.

Hedenquist JW, Arribas A Jr, Reynolds TJ.1998. Evolution of an intrusioncentered hydrothermal system: Far Southeast Lepanto porphyry and epithermal $\mathrm{Cu}-\mathrm{Au}$ deposits, Philippines. Economic Geology, 93 (4) p 373-404.

Morrison, G., Guoyi, D., dan Jaireth, S., 1990. Textural Zoning in Epithermal Quartz Veins. Klondike Exploration Services, p. 35.

Sutopo Bronto, 2013. The Martabe Au-Ag High-Sulfidation Epithermal Deposits, Sumatra, Indonesia: Implications for Ore Genesis and Exploration. University of Tasmania: Australia, p. 332.

\begin{tabular}{|ll|}
\hline Diterima & $:$ 17 Agustus 2020 \\
Direvisi & $:$ 12 September 2020 \\
Disetujui & $:$ 28 November 2020 \\
\hline
\end{tabular}

